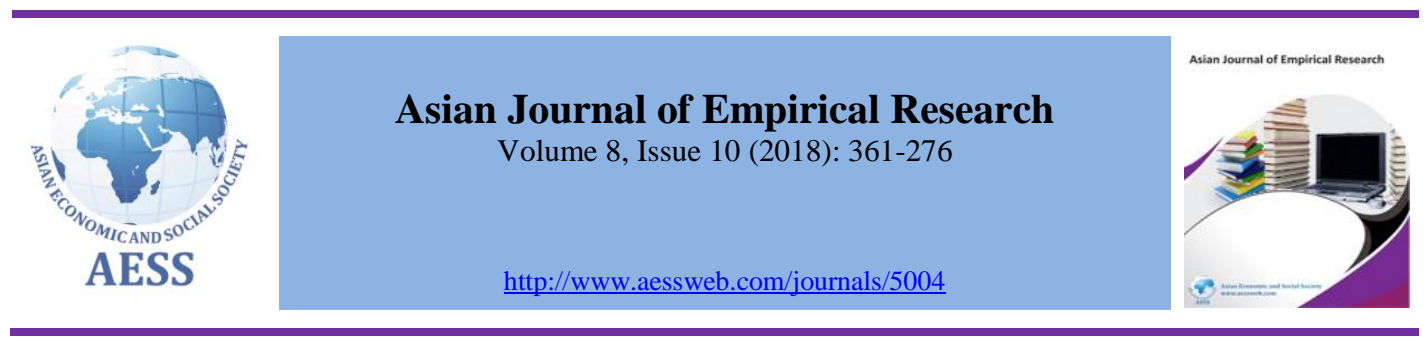

\title{
Bank's stability through risk factors growth and capital ratio: evidence from Kuwait
}

\author{
Ahmed Nahar Al Hussaini \\ The Public Authority for Applied Education \& Training. The College of Business Studies, \\ Kuwait \\ $\bowtie$ drahmednahar@gmail.com Corresponding author
}

\section{ARTICLE HISTORY:}

Received: 20-Sep-2018

Accepted: 08-Nov-2018

Online available: $26-\mathrm{Nov}-$ 2018

\section{Keywords:}

Economic growth, Bank's stability, Liquidity risk, Credit risk

\begin{abstract}
The objective of present study is to examine the effect of risk factors, and capital ratio along business and economic growth in stability of the banks in the case of Kuwait. For this purpose, 10 banks are selected for time period of 2010 to 2016, with the annual observations. Panel regression models like fixed and random effect are applied to check the significance of selected predictors on outcome factors of the study. The results of the study explain that there exists a significant impact of risk factors like liquidity and credit on the stability of the selected banks in the region of Kuwait. In addition, operational efficiency in the form of total expenditure as percent of total assets are also playing critical role. This study is contributing in existing literature from the context of stability and risk with the provision of some useful results.
\end{abstract}

\section{Contribution/ Originality}

This study examines the effect of risk factors, and capital ratio along business and economic growth in stability of the banks, currently working in Kuwait using the data of 10 banks.

DOI: 10.18488/journal.1007/2018.8.10/1007.10.361.376

ISSN (P): 2306-983X, ISSN (E): 2224-4425

CrossMark

How to cite: Ahmed Nahar Al Hussaini (2018). Bank's stability through risk factors growth and capital ratio: evidence from Kuwait. Asian Journal of Empirical Research, 8(10), 361-376.

(C) 2018 Asian Economic and Social Society. All rights reserved 


\section{INTRODUCTION}

In the present business environment, the link between the key risk factors, its management and financial stability of the business firms is under significant observation by the researchers. Proper risk management practices can lead to financial stability, financial fortune, efficiency and financial outcomes in a better way. To work in competitive environment, business firms must deal with various risk factors under the situation of uncertainty and financial fragility (Williams and Heins, 1985). Various studies have taken into accounting the factor of liquidity and credit risk along with the operational efficiency of the baking firms in the current business environment. The factors of risk and uncertainty are under the significant consideration to increase the financial performance of the banking firms as well (Wagner and Bode, 2008).

In the sector of economics, finance and financial market, the integration of risk and financial stability through consideration of financial performance is very much important. Banks and other business firms have increased the level of risk in their business while providing more and more borrowings over time to those who are not able to pay them back (Hassan and Mohammed, 2007). To cover the problem of this risk and uncertainty in the banking firms and to increase the financial stability, Basel regulations have been introduced in the banking firms under the title of Basel Accords. Such practices have provided some sound practices in the banking firms with the lowering impact of liquidity and credit risk specially. To increase the significance of risk management models, increasing financial stability is among the top priorities for the decision makers and for the investors as well. Risk Management practices and procedures are very well recognized which enables the business enterprise for the better integration of systematic and no mitotic risk factors (Raghavan, 2003; Stulz, 2015).

From the perspective of banking sector of Kuwait, it is found that financial intermediation is going on a growth track and shows significant improvement in 2016. The growth for the banking firms in Kuwait is found to be very much slow. Graph 1 explains the growth of the banking firms in Kuwait since 2011 to 2016. The graphs regarding assets, loans to nominal GDP, Assets to NGDP and Deposits to GDP have shown significant increasing trend over last 6 years.

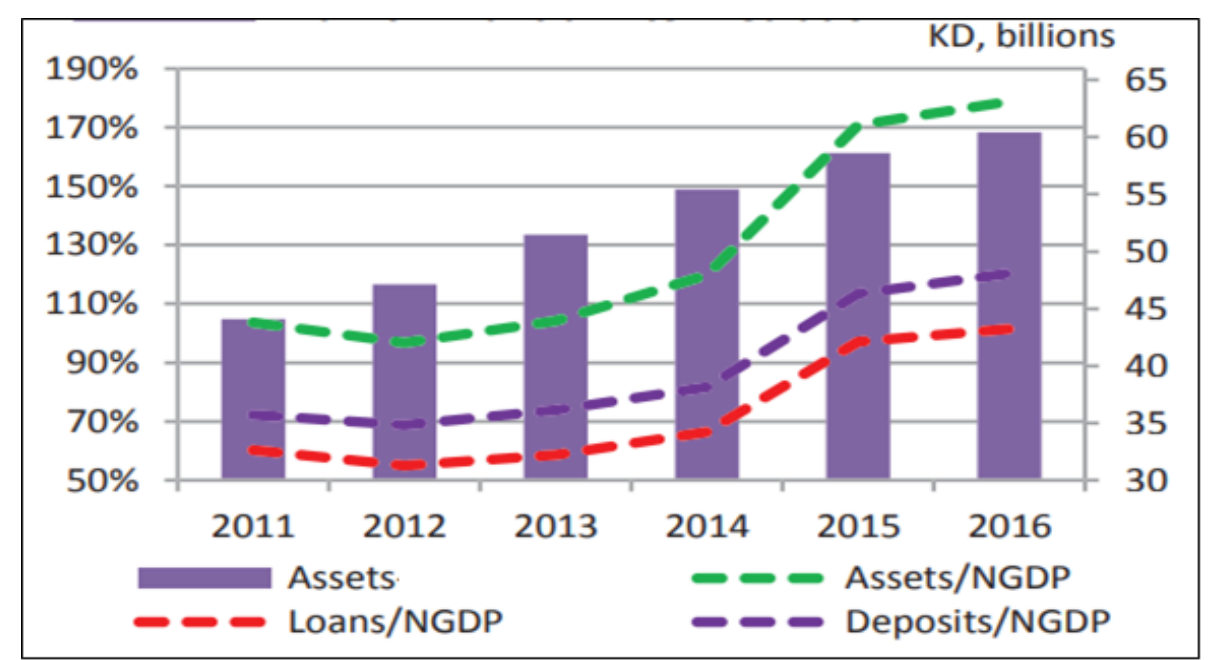

Figure 1: Growth of the banking firms in Kuwait

Source: Central Bank of Kuwait, 2016

In addition, the overall banking sector in financial market of the Kuwait covers, $84 \%$ share along other financial market role players. Investment companies stand at the $2^{\text {nd }}$ position with the share of $12 \%$ in overall market. In overall banking sector, conventional banking firms cover the $60 \%$ share 
since 2016. While Islamic banking firms are covering $37.4 \%$ of the market share which indicates some reasonable share of the market and growth perspective. Figure 2 explains the overall assets growth for the conventional, Islamic special and finally the share of conventional in Islamic as well.

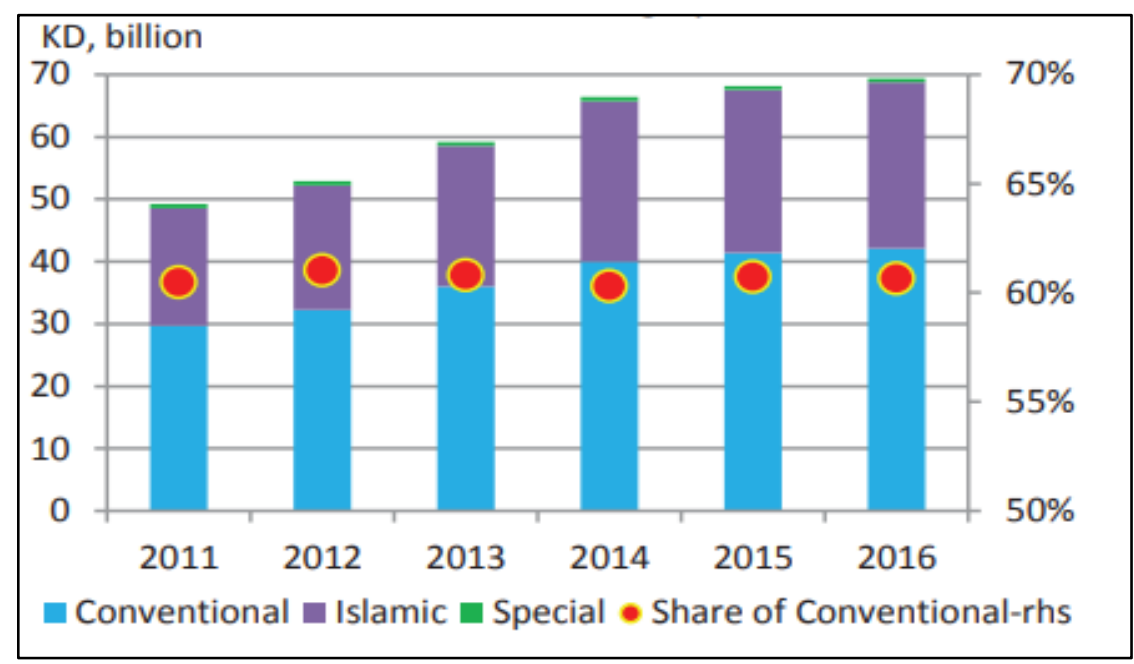

Figure 2: Share of banking firms in financial market of Kuwait

Source: Central Bank of Kuwait, 2016

Besides, the gross loans as provided by the banking sector have covered the various types of borrowers, which explain a mixed trend of borrowing. However, some of the sector like households and real estates are found to be the highest borrowers as compare to investment companies, oil and gas and other sectors. Figure 3 explains the overall gross loans trend in the economy of Kuwait based on the various borrows in 2015 and 2016 respectively.

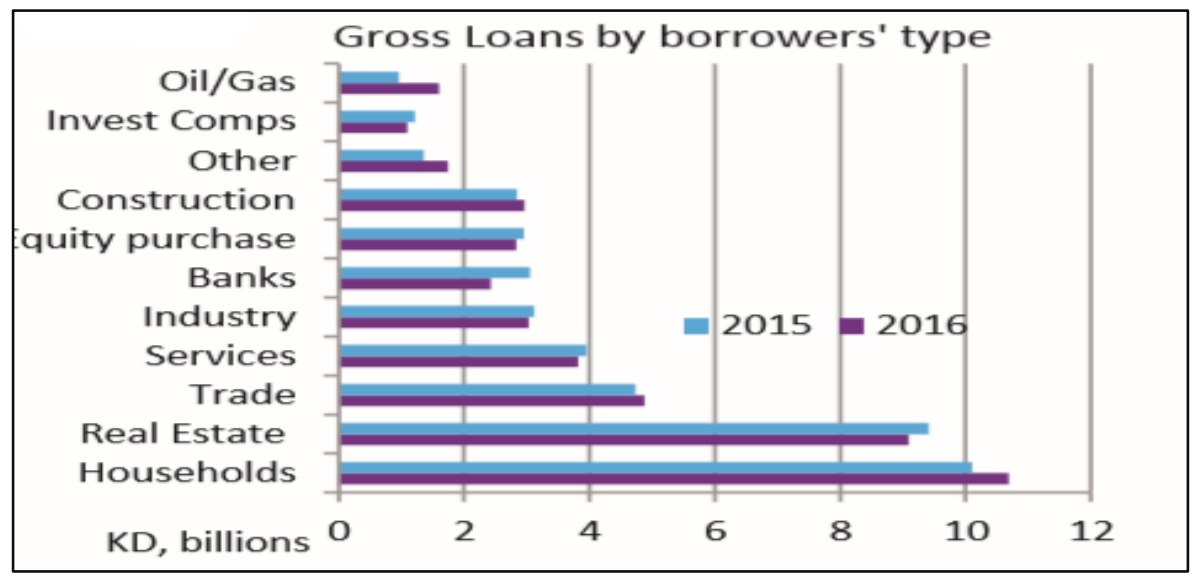

Figure 3: Gross loans by borrowers in Kuwait

Source: Central Bank of Kuwait, 2016

Meanwhile it is also found that in recent years, the liquidity and market risk exposures for the banking firms in Kuwait are assumed to be steadily declined and equity investment stands around $19.2 \%$ as per the share of total investment. The newly introduced liquidity coverage ratio indicates the fact that banking firms are above the comfortable level and far away from the bankruptcy level. In addition, the earnings output in the form of profitability explains the growth rate of $5.8 \%$ in 2016 
which was slower than the growth in the year 2015; 7\% approximately. Meanwhile industry has experienced some increased in the income in the form of higher interest income, with lower loan loss provisions and lower non-interest income as well. The solvency of the banking firms in the shape of capital adequacy ratio is improved to $18.6 \%$ in recent year as per the findings of stability report of 2016. Based on the overall position in recent time, it is found that banking firms in the Kuwait can remain resilient and under the title of New Kuwait leads the country to better stability and leader in trade, finance and culture as well.

Besides, this study is contributing in present literature in various ways. At first, it is using the samples of various banking firms working in the region of Kuwait as per the latest time duration. In the sample of the study both local and international banking firms have been considered with their liquidity risk, credit risk, operational efficiency, capital ratio, and growth perspective for the better performance and stability. Various risk sources have been addressed in existing literature but from the context of Kuwait very little attention is paid for their integration with the stability indicators like return on assets. Moreover, recent financial crisis in the last decade has impacted on the various banking firms in the world which has pushed the banking management to focus on the factors of stability and better financial outcomes. The $2^{\text {nd }}$ contribution by present study is that it has extended the present literature from the concept of stability, risk and growth dimensions while taking both the business growth (total assets) and country growth in the form of GDP. For this purpose, total assets of the selected banks have been taken as log amount with the growth rate in the real economy over 2010 to 2016. For the measurement of stability literature work is widely presented on the profitability measures but its association with the growth is not very much empirically examined. The third significant contribution by the present study is that it is using panel regression models like fixed and random effect which can provide more reliable output while controlling the heterogeneity, error term effects and other problems in the panel data. Besides, this study is going to take the two alternative measures of stability return on assets after tax and return on assets before tax from the context of Kuwait which is not previously taken into consideration from the context of Kuwait.

\section{LITERATURE REVIEW}

In present literature various studies have been conducted which are integrating the idea of risk, capital and financial stability in the banking firms. The context of liquidity risk with the financial performance through some profitability measures has been addressed in existing literature. For instance, Ahmed et al. (2011) explained the fact that size of the banking firms, have their significant and positive linkage with the various risk factors. For the risk factors major focus is on the liquidity and credit risk which are under greater attention to measure the financial distress in various studies. Meanwhile the linkage of operational efficiency and liquidity risk has also been empirically examined and found to have positive and significant association in present literature. Akhtar et al. (2011a; 2011b) expresses the outcome that liquidity risk in both the Islamic and conventional banking firms is very much important for the better performance over time. The same findings have been extracted in the study of Jaffar and Manarvi (2011) who considered the banking firms in Pakistan with the capital adequacy ratio or CAR and its association with the liquidity and leverage ratio as well.

Besides the liquidity risk, world economy in present time is also facing the problem of low asset quality in higher credit risk like increasing non- performing loans (NPLs) for the banking firms (Avgouleas and Goodhart, 2017; Klein, 2013; Louzis et al., 2012; Vouldis and Louzis, 2018). The increasing trend in the value of NPLs is assumed to be among the key hurdles which are stopping the banking firms for the significant growth. Research conducted by Said (2018) explains that banking firms have faced higher level of NPLs before the time of their failure in the financial market. Unlike the other firms in the world economy the failure effect of banking firms will be spread to other firms which can significantly lower the financial results at the end. This effect can be viewed in the last decade when the financial crisis in 2008 were spread out to the world economy, hitting the banking sector directly (Cornett et al., 2011; Saunders and Allen, 2010). Empirical evidence explains that 
financial system and related development in the banking firms are significantly affected by the credit risk which lowers the value of financial stability over time. Besides, Ang and McKibbin (2007) and Levine (1999) have provided the idea that financial development and growth in the economy depends on the value of banking sector growth and development.

Banking firms sometime have shown their negative NPV because of not favorable projects. Meanwhile during the recession time with the banking firms have higher NPLs with the tight capital ratio the management decision to increase the credit related standards seems to be not very much effective. However, borrowing to those creditors who have the good payment background will serve in a reasonable way to boost the financial stability, increasing asset quality and lower credit risk as well.

Besides the credit and liquidity risk, the effect of operational risk for the banking firms on the financial performance and stability indicators is also examined in present literature. For instance, Power (2004) explains that operational risk is not a new risk for the banking firms and it involves the failure of internal process, procedures or operations conducted the business. However, the core concept of operational risk is explained under the words that systematic failure because of weaker internal system by the banks (Jorion, 2000).

Besides the variety of operational risk factors for the banking firms, it is found that most important point is to manage all the available risk factors which are affecting the financial performance of the banking firms. Such approach provides the view of not focusing specially on one factor of risk but to consider them all for the financial stability (Kamran et al., 2016; Kamran et al., 2016; Karman and Malik, 2016; Power, 2005).

The association between the capital levels in the business especially the banks, risk and financial stability is also under consideration in present literature work. This association is examined based on the individual sample as well as the overall sample of various studies. The capital ratio or CAR has been focused by many researchers and financial regulators as it is among the core indicators of profitability and valuable financial outcomes for the business as expressed by Bourke (1989). However, in the earlier time some of the researchers have provided their opinion (Modigliani and Miller, 1958). Some other researchers have the view point that banking firms have their enough capital to secure them from various risk factors in the market place. The banking regulations which are reflected in the form of capital ratio can be a key role player to stop various externalities. Brewer et al. (2000) found that for the shareholders and their interest, capital structure is an important managerial tool and decision-making variable which can maximize the wealth of the banks over time. The portion of defined capital structure can directly impact on the value of loan amount of the banks. Johnson and Rice (2008) indicate the fact that capital ratio measures provide the meaningful information regarding the return of the business over time. Meanwhile some other indicators provide the information for the asset quality and earnings as well. Size and growth volume of the firm can significantly lead to the more earning capacities. His study establishes the fact that change in the overall value of the business assets can lead to the more economic output. However, increasing the investment without any operational efficiency will also provide negative return to the business over time.

The value of cost in the business as expressed through cost to income ratio is a key indicator which has a direct and indirect impact on the value of earnings capacity of the business (Burger and Moormann, 2008; Hulchanski, 1995; Modigliani and Miller, 1963; Tripe, 1998). In the study of (Tripe, 1998) it is found that in measuring the bank efficiency, the role cost to income ratio is very much significant. The value of CIR is significantly used to measure the operating cost of the bank which has a direct impact on earning of the business. Besides, it also works as standard benchmark for the total income which covers both the interest and non-interest income for the banking firms. Bris et al. (2006) also help to address the issue that either the effect of CIR on the earnings of the banks is significant or not. While measuring the income of the business the core indicators like 
return assets and return on equity are under consideration in majority of the studies. It is also expressed as core indicator to express the performance benchmark in almost all types of industries either working in the domestic market or international market (Griffith, 2001; Katzenstein, 1985).

The value of Gross domestic product or GDP and its growth rate in the economy measures the national output during a specific period. Increasing level of production output in the economy significantly affects the business firms like banks as more loan will required financing raw material and other production process and items (Ang et al., 2006; Bacha, 1990; Jiménez and Sánchez, 2005). In addition, increasing growth rate of GDP in the economy have its positive influence on the earning capacity of the business over time. While lowering the GDP growth will lead to the instability in the economy, hence lower performance for the business firms. Increasing growth rate leads to higher economic activities and greater demand for both interest and non-interest activities due to lower default risk in the higher economic output and hence its positive influence on profitability and stability of the banks.

\section{DESCRIPTION OF THE VARIABLES AND HYPOTHESES}

For the panel analysis of the study, two outcome variables under the title of ROAAT and ROABT have been selected which measure the performance of the banks over time (Burton et al., 2002; Molyneux and Thornton, 1992). To calculate the ROAAT or return on assets after tax, net income of the business after paying all the expenses over time is divided over total assets of the business in the following way.

$$
\text { ROAAT }=\frac{\text { Net Income }}{\text { Total assets }}
$$

For the measurement of return on assets before tax, following equation is under consideration

$$
R O A B T=\frac{\text { Net Income }}{\text { Total assets }}
$$

for the first explanatory variable, loan to asset ratio is considered. This ratio measures the ability of the firm regarding how much the loan amount is provided against the total assets of the business over time. Following Equation is explaining the measurement of first explanatory variable of the study.

$$
L O T A R=\frac{\text { Loans provided by the Business }}{\text { Total assets }}
$$

For the $2^{\text {nd }}$ explanatory variable of the study, cash and cash equivalent to total asset ratio or CACETAR is under consideration. This ratio is also used for the measurement of liquidity risk in the banks. Higher this ratio means more liquid assets for the business. Following formula is considered to calculate CACETAR in the study

$$
\text { CACETAR }=\frac{\text { cash and cash equivalent }}{\text { Total assets }}
$$

The third predictor is entitled as the capital ratio, which measures the adequacy of the capital in the business to secure the business from uneven financial shocks over time. This ratio is also used to measure the stability of the business over time.

$$
\text { CTALEV }=\frac{\text { Total Capital }}{\text { Total assets }}
$$


The fourth indicator is entitled under loan loss provision to total loans, which measures the asset quality over time. The same ratio is used to express the level of credit risk in the business over time. Higher this ratio means lower asset quality and more credit risk. The ratio is as follows:

$$
\text { LLPTL }=\frac{\text { Loan Loss Provisions }}{\text { Total Loans }}
$$

To measure the operational efficiency of the business, total expenditure as a $\%$ of total assets of the business is selected. This ratio explains the ratio of overall expenditure incurred by the bank over time. Higher expenses mean lower performance and vice versa. Besides, funding cost is also considered to measure the operational efficiency over time. Besides, total assets of the business are the core indication for the growth and better performance. While for the economic growth the role of gross domestic product is very much significant. Present study has also considered the GDP growth rate among the other explanatory variables of the study. Based on the variables, following hypotheses have been developed for the first outcome factor, ROAAT.

Ha: ROAAT is significantly determined by value of LOTAR for the selected banks. $\mathrm{Hb}$ : ROAAT is significantly determined by value of CACETAR for the selected banks. HC: ROAAT is significantly determined by value of CTALEV for the selected banks. Hd: ROAAT is significantly determined by value of LLPTL for the selected banks. He: ROAAT is significantly determined by value of TEATA for the selected banks. Hf: ROAAT is significantly determined by value of FUNDCOST for the selected banks. $\mathrm{Hg}$ : ROAAT is significantly determined by value of LOGTA for the selected banks. Hh: ROAAT is significantly determined by value of GDPGR for the selected banks.

For the $2^{\text {nd }} \mathrm{DV}$, following research hypotheses will be examined:

H1: ROABT is significantly determined by value of LOTAR for the selected banks. $\mathrm{H} 2$ : ROABT is significantly determined by value of CACETAR for the selected banks. H3: ROABT is significantly determined by value of CTALEV for the selected banks. H4: ROABT is significantly determined by value of LLPTL for the selected banks. H5: ROABT is significantly determined by value of TEATA for the selected banks. H6: ROABT is significantly determined by value of FUNDCOST for the selected banks. H7: ROABT is significantly determined by value of LOGTA for the selected banks. H8: ROABT is significantly determined by value of GDPGR for the selected banks.

\section{RESEARCH METHODOLOGY}

To empirically examine the effect of selected factors of risk, capital ratio and GDP, panel regression equations have been development. The key advantage of panel regressions is that they can control the effect of heterogeneity and unobserved variables over time (Gujarati, 2009). For the panel models, pooled regression, least square dummy variable model, fixed effect and finally the random effect model equation is developed. Following regression equations have been developed for the first outcome factor of ROAAT

$$
\begin{aligned}
& Y(\text { ROAAT })=\partial+\beta_{1} L O T A R C R+\beta_{2} \text { CACETARLIQ }+\beta_{3} C T A L E V+\beta_{4} L L P T L+\beta_{5} \text { TEATA }+ \\
& \beta_{6} \text { FUNDCOST }+\beta_{7} L O G T A+\beta_{8} \text { GDPGR }+\varepsilon
\end{aligned}
$$

Equation 1 explains the pooled regression model which is very much useful while controlling the effect of other factors which are not being observed in the model. Eight explanatory variables under the title of LOTARCR, CACETARLIQ, CTALEV, LLPTL, TEATA, FUNDCOST, LOGTA, and GDPGR are added in the equation, while $\partial$ represents the fixed value of ROAAT even there is no explanatory variable in the regression model. $\beta_{1}, \beta_{2} \sim \beta_{8}$ explains the regression coefficients for 
the pooled regression model. To control and demonstrate the effect of individual entities over the regressors and outcomes factor, following LSDVM regression equation is developed for ROAAT.

$$
\begin{aligned}
& Y(\text { ROAAT })=\partial+\beta_{1} \text { LOTARCR }+\beta_{2} \text { CACETARLIQ }+\beta_{3} \text { CTALEV }+\beta_{4} L L P T L+\beta_{5} \text { TEATA }+ \\
& \beta_{6} \text { FUNDCOST }+\beta_{7} L O G T A+\beta_{8} \text { GDPGR }+\partial_{2} \text { Bnk } 2_{2 i t}+\partial_{10} \text { Bank } 10_{10 i t}+\varepsilon_{i t} \varepsilon
\end{aligned}
$$

Besides, for the regression coefficients, the effect of individual entities is presented through $\partial_{2} B n k 2_{2 i t} \square \partial_{10} B a n k 10_{10 i t}$, with the error terms. Meanwhile, the fixed effect regression equation is presented below, which controls the effect of entities over time. based on this assumption, equation 3 will remain the same as equation 2, which is as follows:

$$
\begin{aligned}
& Y(\text { ROAAT })=\partial+\beta_{1} \text { LOTARCR }+\beta_{2} \text { CACETARLIQ }+\beta_{3} C T A L E V+\beta_{4} L L P T L+\beta_{5} \text { TEATA }+ \\
& \beta_{6} \text { FUNDCOST }+\beta_{7} L O G T A+\beta_{8} \text { GDPGR }+\partial_{2} B n k 2_{2 i t}+\partial_{10} \text { Bank } 10_{10 i t}+\varepsilon_{i t} \varepsilon
\end{aligned}
$$

After the fixed effect model, the random effect equation is developed which assumes that entities over time can't influence over the predictors and error terms are random in the model. Equation 4 is based on this assumption which is presented below.

$$
\begin{aligned}
& Y(\text { ROAAT })=\partial+\beta_{1} \text { LOTARCR }+\beta_{2} \text { CACETARLIQ }+\beta_{3} \text { CTALEV }+\beta_{4} L L P T L+\beta_{5} \text { TEATA }+ \\
& \beta_{6} \text { FUNDCOST }+\beta_{7} L O G T A+\beta_{8} \text { GDPGR }+\partial_{2} \text { Bnk } 2_{2 i t}+\partial_{10} \text { Bank } 10_{10 i t}+U_{i}+W_{i j}
\end{aligned}
$$

For the $2^{\text {nd }} \mathrm{DV}$; ROABT, regression equations have been developed on the same pattern as above. Equations are as follows:

$$
\begin{aligned}
& Y(\mathrm{ROABT})=\partial+\beta_{1} \text { LOTARCR }+\beta_{2} \text { CACETARLIQ }+\beta_{3} \text { CTALEV }+\beta_{4} L L P T L+\beta_{5} \text { TEATA }+ \\
& \beta_{6} \text { FUNDCOST }+\beta_{7} L O G T A+\beta_{8} G D P G R+\varepsilon \\
& Y(\mathrm{ROABT})=\partial+\beta_{1} \text { LOTARCR }+\beta_{2} \text { CACETARLIQ }+\beta_{3} \text { CTALEV }+\beta_{4} L L P T L+\beta_{5} \text { TEATA }+ \\
& \beta_{6} \text { FUNDCOST }+\beta_{7} L O G T A+\beta_{8} G D P G R+\partial_{2} B n k 2_{2 i t}+\partial_{10} \text { Bank } 10_{10 i t}+\varepsilon_{i t} \varepsilon \\
& Y(\mathrm{ROABT})=\partial+\beta_{1} \text { LOTARCR }+\beta_{2} \text { CACETARLIQ }+\beta_{3} \text { CTALEV }+\beta_{4} L L P T L+\beta_{5} \text { TEATA }+ \\
& \beta_{6} \text { FUNDCOST }+\beta_{7} \text { LOGTA }+\beta_{8} \text { GDPGR }+\partial_{2} \text { Bnk } 2_{2 i t}+\partial_{10} \text { Bank } 10_{10 i t}+\varepsilon_{i t} \varepsilon \\
& Y(\mathrm{ROABT})=\partial+\beta_{1} \text { LOTARCR }+\beta_{2} \text { CACETARLIQ }+\beta_{3} \text { CTALEV }+\beta_{4} L L P T L+\beta_{5} \text { TEATA }+ \\
& \beta_{6} \text { FUNDCOST }+\beta_{7} \text { LOGTA }+\beta_{8} \text { GDPGR }+\partial_{2} \text { Bnk } 2_{2 i t}+\partial_{10} \text { Bank10 } 10 i t+U_{i}+W_{i j}
\end{aligned}
$$

where ROAAT measures return on assets after tax, ROABT measures return on assets before tax, LOTARCR measures the loan to assets ratio for the current measure of liquidity, CACETARLIQ measures the cash and cash equivalent to total assets ratio for the $2^{\text {nd }}$ measure of liquidity, CTALEV measures the capital to assets ratio (leverage), LLPTL measures the loan loss provision to total loans (credit risk), TEATA measures total expenditure as $\%$ of total assets ratio as operational efficiency of the firm, FUNDCOST measures the funding cost, LOGTA measures the log of total assets, and finally GDPGR measures the gross domestic product growth rate over the time period of the study. For the panel regression models, the key techniques are under the title of fixed effect and random effect, while the comparison between the both models will be conducted through Hausman test. To apply both the fixed and random effect is the fundamental requirement for the panel data as applied in numerous empirical studies. 


\section{RESULTS AND DISCUSSIONS}

For the analysis of the study, two major techniques are under consideration; descriptive and inferential outcomes. Table 1 explains the descriptive outcomes of the study which is used to express the trend of the data set. Overall observation for each of the predictors and outcome variable is 70 which indicate no missing observation over the time of the study. The mean value of ROAAT is 0.010 with the deviation of 0.0104 , for the ROABT is 0.015 and 0.016 respectively. For the risk factors like liquidity, LOTARCT indicates a mean of .558 with the deviation of 0.094 . For the credit risk LLPTL, mean value is 0.070 with the deviation of 0.051 . The mean value of log total assets indicates a maximum average point 7.52 with the standard deviation of 2.53 . The range of log total assets ranges from 0.04 to 9.09 . The overall data set indicates that trend is reasonable for the further panel regression analysis.

\section{Table 1: Descriptive statistics}

\begin{tabular}{lccccc}
\hline Variable & Obs. & Mean & Std. Dev. & Min & Max \\
\hline ROAAT & 70 & 0.011 & 0.011 & -0.042 & 0.030 \\
ROABT & 70 & 0.016 & 0.016 & -0.077 & 0.041 \\
LOTARCR & 70 & 0.559 & 0.095 & 0.356 & 0.993 \\
CACETARLIQ & 70 & 0.124 & 0.048 & 0.028 & 0.263 \\
CTALEV & 70 & 0.079 & 0.036 & 0.005 & 0.200 \\
LLPTL & 70 & 0.070 & 0.052 & 0.005 & 0.242 \\
TEATA & 70 & 0.082 & 0.026 & 0.011 & 0.169 \\
FUNDCOST & 70 & 0.050 & 0.029 & 0.006 & 0.137 \\
LOGTA & 70 & 7.521 & 2.538 & 0.045 & 9.096 \\
GDPGR & 70 & 5.176 & 2.038 & 1.596 & 7.667 \\
\hline
\end{tabular}

After the descriptive outcomes, in next step inferential analysis has been conducted. For this purpose, panel models like pooled regression, dummy variable model, fixed effect and random effect is applied. Two major outcome factors under the title of return on assets after tax (ROAAT) and return on assets before tax (ROABT) are selected with the set of predictors. Table 2 explains the regression outcome for the very first model, taking ROAAT as $1^{\text {st }}$ dependent variable. The impact of first proxy for the liquidity risk (LOTARCR) indicates a negative \& insignificant impact of 0.0014 on the value of ROAAT. The impact of $2^{\text {nd }}$ proxy of liquidity risk (CACETAR) is 0.0356 which is insignificant at $05 \%$ level of confidence. The third independent variable is entitled under capital to asset ratio which indicates the leverage for the selected banks have also represents a negative but insignificant impact on ROAAT. However, for the credit risk factor of loan loss provision to total loans has shown negative and significant impact on ROAAT. The coefficient of LLPTL is -0.119 with the t-statistics of 2.71 . This value is above the threshold point of 1.96 which indicates the acceptance region for the effect of LLPTL on ROAAT. The rest of the indicators under pooled regression in table 2 explained insignificant impact. The overall goodness of the model indicates the f-vale of 5.05 which is above 3.50 and significant at $5 \%$ level of significance. It indicates that regression equation for the ROAAT under pooled analysis is fit. The value of R-square indicates the overall variation of 39.82 in ROAAT as explained by all the predictors in equation 1 of the study. The reason for this overall variation is purely based on the explanatory power of LLPTL which means that overall $39 \%$ explained variation is totally belong to credit risk in the selected firms. Another reason for this effect is that in financial sector credit risk is among the key risk factors with which management has to deal with.

To control the effect of selected entities which can vary over time, fixed effect under the title of least square model is applied through regression equation 2 for the ROAAT. Least square dummy variable model not only controls the effect of individuals dummy but also spread that controlling effect over created dummies. Table 3 explains the regression outcomes for the LSDVM. As per the stated findings, the effect of LLPTD is found to be significant and negative on ROAAT, indicating that credit risk is negatively affecting the financial performance of selected banks over time. In 
addition, the effect of funding cost is assumed to be positive for the ROAAT. The value of coefficient for the FUNDCOST is .164 with the t-value of 2.28. The effect of GDPGR is assumed to significant and positive with the coefficient of .001. The rest of the indicators under LSDVM explain insignificant impact on the value of ROAAT. The fitness of the model indicates a good sign as fvalue is 10.24 , significant at $1 \%$. The value of R-square and adjusted R-square has shown a good level of explained variation; $76.99 \%$ and $69.47 \%$ respectively.

Table 2: Pooled regression results

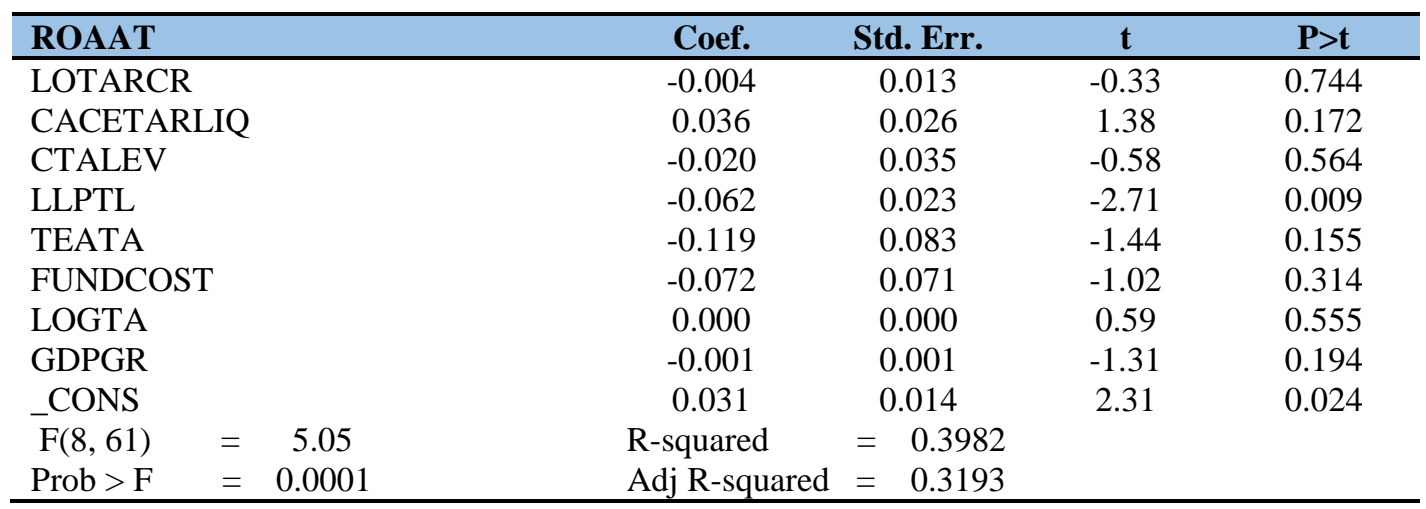

Table 3: LSDVM regression results

\begin{tabular}{|c|c|c|c|c|c|}
\hline \multicolumn{2}{|c|}{ ROAAT } & Coef. & Std. Err. & $t$ & $P>t$ \\
\hline \multicolumn{2}{|c|}{ LOTARCR } & 0.001 & 0.010 & 0.1 & 0.918 \\
\hline \multicolumn{2}{|c|}{ CACETARLIQ } & -0.023 & 0.025 & -0.9 & 0.37 \\
\hline \multicolumn{2}{|c|}{ CTALEV } & -0.001 & 0.030 & -0.05 & 0.963 \\
\hline \multicolumn{2}{|l|}{ LLPTL } & -0.132 & 0.022 & -6.11 & $0.000 * * *$ \\
\hline \multicolumn{2}{|c|}{ TEATA } & -0.101 & 0.077 & -1.3 & 0.198 \\
\hline \multicolumn{2}{|c|}{ FUNDCOST } & 0.165 & 0.072 & 2.28 & $0.026 * *$ \\
\hline \multicolumn{2}{|c|}{ LOGTA } & 0.000 & 0.004 & 0.02 & 0.98 \\
\hline \multicolumn{2}{|l|}{ GDPGR } & 0.001 & 0.001 & 1.71 & $0.093^{*}$ \\
\hline $\mathrm{F}(17,52)$ & 10.24 & R-squared & 0.7699 & & \\
\hline Prob > F & $=0.0000$ & Adj R-squared & 0.6947 & & \\
\hline
\end{tabular}

After the LSDVM, table 4 explains the regression coefficient for the fixed effect model. It is found that the effect of LLPTL under fixed effect is also found to be negative with the coefficient of -.131 significant at $01 \%$ level of significance. The effect of funding cost is also found to be positively significant at $5 \%$ level of significant. Meanwhile the effect of GDPGR under fixed effect regression equation is positive and significant at $10 \%$ level of significant. The rest of the indicators for the ROAAT like liquidity risk, leverage and total assets are explaining insignificant impact.

Table 4: Fixed effect regression results

\begin{tabular}{lcccc}
\hline ROAAT & Coef. & Std. Err. & t & P>t \\
\hline LOTARCR & 0.001 & 0.010 & 0.1 & 0.918 \\
CACETARLIQ & -0.023 & 0.025 & -0.9 & 0.37 \\
CTALEV & -0.001 & 0.030 & -0.05 & 0.963 \\
LLPTL & -0.132 & 0.022 & -6.11 & $0.000^{* * *}$ \\
TEATA & -0.101 & 0.077 & -1.3 & 0.198 \\
FUNDCOST & 0.165 & 0.072 & 2.28 & $0.026^{* *}$ \\
LOGTA & 0.000 & 0.004 & 0.02 & 0.98 \\
GDPGR & 0.001 & 0.001 & 1.71 & $0.093^{*}$ \\
cons & 0.016 & 0.034 & 0.48 & 0.635 \\
\hline
\end{tabular}




\begin{tabular}{llc}
\hline $\mathrm{F}(8,52)$ & $=$ & 6.97 \\
Prob $>\mathrm{F}$ & $=$ & 0.0000 \\
\hline
\end{tabular}

The findings of random effect regression model are presented in table 5. It is found that regression coefficient for the LLPTL is negatively significant at $1 \%$ level of significance. The impact of rest of the indicators under random effect model is found to be insignificant. The value of goodness of the fit for the random effect is explaining a significant result as $\mathrm{P}_{-}$Value for the Wald-chi-square is significant at $1 \%$ level of significant.

Table 5: Random effect regression results

\begin{tabular}{|c|c|c|c|c|}
\hline ROAAT & Coef. & Std. Err. & $\mathbf{Z}$ & $\mathbf{P}>\mathbf{z}$ \\
\hline LOTARCR & -0.002 & 0.012 & -0.16 & 0.873 \\
\hline CACETARLIQ & 0.022 & 0.026 & 0.84 & 0.399 \\
\hline CTALEV & -0.010 & 0.032 & -0.32 & 0.751 \\
\hline LLPTL & -0.085 & 0.023 & -3.73 & $0.000 * * *$ \\
\hline TEATA & -0.093 & 0.081 & -1.15 & 0.25 \\
\hline FUNDCOST & 0.003 & 0.072 & 0.04 & 0.969 \\
\hline LOGTA & 0.000 & 0.001 & 0.74 & 0.46 \\
\hline GDPGR & 0.000 & 0.001 & -0.24 & 0.814 \\
\hline _cons & 0.021 & 0.013 & 1.58 & 0.114 \\
\hline$\overline{\text { Wald }}$ chi2(8) & & & & \\
\hline Prob $>$ chi $2=0.0000$ & & & & \\
\hline
\end{tabular}

To conduct the comparison between the fixed effect and random effect, Hausman test is applied. For this purpose, the difference in the coefficient for the fixed and random effect is examined based on the following hypotheses.

Ho: Difference in the coefficient is not systematic / random effect is accepted for the decision making.

H1: Difference in the coefficient in systematic /fixed effect is accepted for the decision making.

Table 6 expresses the difference between the coefficient for the fixed and random effect. It is found that the difference between the coefficients is statistically significant a chi 2 value is significant at $1 \%$ level of significance. In this case, findings are in favor for the fixed effect model and for ROAAT, H1 will be accepted for the Hausman test.

Table 6: Hausman test results: ROAAT

\begin{tabular}{lccc}
\hline & $\begin{array}{c}\text { (b) } \\
\text { fixed }\end{array}$ & $\begin{array}{c}\text { (B) } \\
\text { random }\end{array}$ & $\begin{array}{c}\text { (b-B) } \\
\text { Difference }\end{array}$ \\
\hline LOTARCR & 0.001 & -0.002 & 0.003 \\
CACETARLIQ & -0.023 & 0.022 & -0.045 \\
CTALEV & -0.001 & -0.010 & 0.009 \\
LLPTL & -0.132 & -0.085 & -0.047 \\
TEATA & -0.101 & -0.093 & -0.008 \\
FUNDCOST & 0.165 & 0.003 & 0.162 \\
LOGTA & 0.000 & 0.000 & 0.000 \\
GDPGR & 0.001 & 0.000 & 0.001 \\
chi2(8)=72.80*** & & & \\
Prob>chi2=.000 & & & \\
\hline
\end{tabular}

For the $2^{\text {nd }} \mathrm{DV}$ of ROABT, findings of pooled regression are presented in table 7 below. The regression coefficient for the LLPTL is negative and significant, indicates that unit change in the value of LLPTL causes a negative and significant impact on the ROABT. For the TEATA, the 
coefficient of -0.22 indicates that increasing expenditures for the selected banks are negatively affecting on the performance of the selected banks. In addition, FUNDCOST has also explained negative and significant impact on ROBT. While the impact of GDPGR under pooled regression for the ROABT is found to be negatively significant at $1 \%$.

Table 7: Pooled regression results for ROABT

\begin{tabular}{lcccc}
\hline ROABT & Coef. & Std. Err & t & P>t \\
\hline LOTARCR & -0.015 & 0.017 & -0.93 & 0.358 \\
CACETARLIQ & 0.027 & 0.034 & 0.8 & 0.425 \\
CTALEV & 0.062 & 0.046 & 1.34 & 0.184 \\
LLPTL & -0.122 & 0.030 & -4.03 & $0.000^{* * *}$ \\
TEATA & -0.225 & 0.109 & -2.07 & $0.043^{* *}$ \\
FUNDCOST & -0.224 & 0.093 & -2.41 & $0.019^{* *}$ \\
LOGTA & 0.000 & 0.001 & 0.41 & 0.681 \\
GDPGR & -0.003 & 0.001 & -3.03 & $0.004^{* * *}$ \\
cons & 0.068 & 0.018 & 3.81 & 0.000 \\
F $(8,61)=9.64$ & R-squared $=.5585$ & & & \\
Prob. $>\mathrm{F}=0.000$ & Adj. R-Squared=.5006 & & & \\
\hline
\end{tabular}

For the LSDVM, findings are presented under table 8 for the $2^{\text {nd }} \mathrm{DV}$; ROABT. The value of coefficients for the liquidity risk measure; CACETAR is negatively significant at $1 \%$ level of significance. Its coefficient indicates that unit change in liquidity risk is positively affecting ROABT for the selected banks. Besides, the impact of credit risk is also found to be negatively significantly at $1 \%$. The rest of the indicators are found to be insignificant at 1,5 and $10 \%$ level of significance.

Table 8: LSDVM findings for ROABT

\begin{tabular}{lcccc}
\hline ROABT & Coef. & Std. & t & P>t \\
\hline LOTARCR & -0.010 & 0.013 & -0.73 & 0.469 \\
CACETARLIQ & -0.031 & 0.032 & -0.96 & 0.342 \\
CTALEV & 0.131 & 0.037 & 3.52 & 0.001 \\
LLPTL & -0.205 & 0.027 & -7.53 & 0 \\
TEATA & -0.139 & 0.098 & -1.43 & 0.16 \\
FUNDCOST & 0.018 & 0.091 & 0.2 & 0.845 \\
LOGTA & 0.007 & 0.005 & 1.58 & 0.119 \\
GDPGR & 0.000 & 0.001 & 0.21 & 0.838 \\
F(17, 52)=16.6*** & & & & \\
Prob>F=.0000 & & & & \\
R-squared=.8444 & & & & \\
Adj R-square $=.7935$ & & &
\end{tabular}

For the fixed effect findings of $2^{\text {nd }} \mathrm{DV}$, variables like capital ratio and credit risk are found to be significantly affecting the ROABT. The value of coeffiecnt for the leverage is -.130 which indicates that unit change in the value of leverage ratio is positively and significantly affecting the ROABT. In addition, the effect of credit risk is also negative and significant under $1 \%$ level of significance. The rest of the indicators like GDPGR and LOGTA are also insignificant.

Table 9: Fixed effect results for ROABT

\begin{tabular}{lcccc}
\hline ROABT & Coef. & Std. & t & P>t \\
\hline LOTARCR & -0.010 & 0.013 & -0.73 & 0.469 \\
CACETARLIQ & -0.031 & 0.032 & -0.96 & 0.342 \\
CTALEV & 0.131 & 0.037 & 3.52 & $0.001^{* * *}$ \\
LLPTL & -0.205 & 0.027 & -7.53 & $0.000^{* * *}$ \\
\hline
\end{tabular}




\begin{tabular}{|c|c|c|c|c|c|}
\hline TEATA & & -0.139 & 0.098 & -2.43 & $0.016^{* *}$ \\
\hline FUNDCOST & & 0.018 & 0.091 & 0.2 & 0.845 \\
\hline LOGTA & & 0.007 & 0.005 & 1.58 & 0.119 \\
\hline GDPGR & & 0.000 & 0.001 & 0.21 & 0.838 \\
\hline _CONS & & -0.015 & 0.043 & -0.35 & 0.728 \\
\hline $\bar{F}(8,52)$ & $=13.45$ & & & & \\
\hline Prob $>$ F & $=0.0001$ & & & & \\
\hline
\end{tabular}

Table 10 explains the regression results under random effect for ROABT. It is found that capital ratio and LLPTL with TEATA has significant impact on ROABT. The impact of TEATA and LLPTL is negatively significant, while the impact of capital ratio is positive and significant. The impact of GDPGR is -.0014, which is significant at $10 \%$. To make a comparison between the fixed and the random effect for the $2^{\text {nd }} \mathrm{DV}$, the value of chi-square is significant; indicating the fact that fixed effect is accepted for the final consideration.

Table 10: Random effect regression results for ROABT

\begin{tabular}{lcccc}
\hline ROABT & Coef. & Std. & $\mathbf{Z}$ & $\mathbf{P}>\mathbf{z}$ \\
\hline LOTARCR & -0.015 & 0.015 & -1.02 & 0.309 \\
CACETARLIQ & -0.002 & 0.033 & -0.07 & 0.943 \\
CTALEV & 0.092 & 0.039 & 2.35 & $0.019^{* *}$ \\
LLPTL & -0.164 & 0.029 & -5.65 & $0.000^{* * *}$ \\
TEATA & -0.173 & 0.103 & -1.69 & $0.091^{*}$ \\
FUNDCOST & -0.101 & 0.093 & -1.08 & 0.278 \\
LOGTA & 0.001 & 0.001 & 0.72 & 0.474 \\
GDPGR & -0.002 & 0.001 & -1.69 & $0.092^{*}$ \\
CONS & 0.051 & 0.017 & 2.93 & 0.003 \\
Wald & chi2 $(8)$ & $=$ & 77.02 & \\
Prob> Chi2=0.0000 & & & & \\
\hline
\end{tabular}

Table 11: Hausman test results: ROABT

\begin{tabular}{lccc}
\hline & $\begin{array}{c}\text { (b) } \\
\text { fixed }\end{array}$ & $\begin{array}{c}\text { (B) } \\
\text { random }\end{array}$ & $\begin{array}{c}\text { (b-B) } \\
\text { Difference }\end{array}$ \\
\hline LOTARCR & -0.010 & -0.015 & 0.005 \\
CACETARLIQ & -0.031 & -0.002 & -0.029 \\
CTALEV & 0.131 & 0.092 & 0.039 \\
LLPTL & -0.205 & -0.164 & -0.041 \\
TEATA & -0.139 & -0.173 & 0.034 \\
FUNDCOST & 0.018 & -0.101 & 0.118 \\
LOGTA & 0.007 & 0.001 & 0.007 \\
GDPGR & 0.000 & -0.002 & 0.002 \\
chi2(8)=109.78*** & & & \\
Prob>chi2=.000 & & & \\
\hline
\end{tabular}

Table 12: Accepted hypotheses under panel regression

\begin{tabular}{llc}
\hline $\begin{array}{l}\text { Regression } \\
\text { Model }\end{array}$ & \multicolumn{1}{c}{ Research Hypotheses } & Status \\
\hline $\begin{array}{l}\text { Fixed Effect } \\
\text { after HM test }\end{array}$ & $\begin{array}{l}\text { Hb: ROAAT is significantly determined by value of CACETAR } \\
\text { for the selected banks }\end{array}$ & Accepted \\
$\begin{array}{l}\text { Fixed Effect } \\
\text { after HM test }\end{array}$ & $\begin{array}{l}\text { Hd: ROAAT is significantly determined by value of LLPTL for } \\
\text { the selected banks }\end{array}$ & Accepted \\
$\begin{array}{l}\text { Fixed Effect } \\
\text { after HM test }\end{array}$ & $\begin{array}{l}\text { He: ROAAT is significantly determined by value of TEATA for } \\
\text { the selected banks }\end{array}$ & Accepted \\
\hline
\end{tabular}




\begin{tabular}{lll}
\hline $\begin{array}{l}\text { Fixed Effect } \\
\text { after HM test }\end{array}$ & $\begin{array}{l}\text { H4: ROABT is significantly determined by value of LLPTL for } \\
\text { the selected banks }\end{array}$ & Accepted \\
$\begin{array}{l}\text { Fixed Effect } \\
\text { after HM test }\end{array}$ & $\begin{array}{l}\text { H6: ROABT is significantly determined by value of FUNDCOST } \\
\text { for the selected banks }\end{array}$ & Accepted \\
$\begin{array}{l}\text { Fixed Effect } \\
\text { after HM test }\end{array}$ & $\begin{array}{l}\text { H8: ROABT is significantly determined by value of GDPGR for } \\
\text { the selected banks }\end{array}$ & Accepted \\
\hline
\end{tabular}

\section{CONCLUSION AND POLICY IMPLICATION}

In the contemporary business environment, the effect of various risk factors, operational efficiency and economic growth on business performance is very much significant. Inefficiency in managing various risk factors will result in more instability for the business firms either working in domestic or international market. Meanwhile operational efficiency is very much necessary to compete in the current business market. The aim of present study is to consider the risk factors, operational efficiency to determine the business performance over time. For this purpose, 10 banks are selected, working in the region of Kuwait. Panel regression models have been applied with the fixed and random effect because of their wider use in existing literature. It is found that factors like liquidity and credit risk are playing their significant role in explaining the performance of the banks. In addition, the effect of operational efficiency for the ROABT through TEATA is found to be significant in random effect model, while the impact of GDPGR is significant for the random effect and pooled regression for the ROABT. For the ROAAT, the effect of GDPGR is found to be significant under LSDVM and FEM. For the log of total assets, it is found that none of the regression model presented the significant effect for both the ROAAT, and ROABT. The above stated findings have the following policy implications in the region of Kuwait.

- Various officials, dealing with the management of risk and uncertainty in the banking firms should follow the findings while going for any significant decision making, specifically in the Kuwaiti region.

- For the significant implication, it is very much obvious to consider the effect of operational efficiency and country level factors like GDP which are affecting the performance of the banks.

\footnotetext{
Funding: This study received no specific financial support.

Competing Interests: The author declares that s/he has no conflict of interests.

Contributors/Acknowledgement: All the designing and estimation of current research done by sole author.

Views and opinions expressed in this study are the views and opinions of the authors, Asian Journal of

Empirical Research shall not be responsible or answerable for any loss, damage or liability etc. caused in relation to/arising out of the use of the content.
}

\section{References}

Ahmed, N., Akhtar, M. F., \& Usman, M. (2011). Risk management practices and Islamic banks: An empirical investigation from Pakistan. Interdisciplinary Journal of Research in Business, 1(6), 50-57. view at Google scholar

Akhtar, M. F., Ali, K., \& Sadaqat, S. (2011a). Factors influencing the profitability of Islamic banks of Pakistan. International Research Journal of Finance and Economics, 66(66), 1-8. view at Google scholar

Akhtar, M. F., Ali, K., \& Sadaqat, S. (2011b). Liquidity risk management: a comparative study between conventional and Islamic banks of Pakistan. Interdisciplinary Journal of Research in Business, 1(1), 35-44. view at Google scholar

Ang, A., Piazzesi, M., \& Wei, M. (2006). What does the yield curve tell us about GDP growth? Journal of econometrics, 131(1-2), 359-403. view at Google scholar / view at publisher 
Ang, J. B., \& McKibbin, W. J. (2007). Financial liberalization, financial sector development and growth: evidence from Malaysia. Journal of Development Economics, 84(1), 215-233. view at Google scholar / view at publisher

Avgouleas45, E., \& Goodhart, C. (2017). Utilizing AMCs to tackle the eurozone's legacy nonperforming loans. Non-Performing Loans, 83. view at Google scholar

Bacha, E. L. (1990). A three-gap model of foreign transfers and the GDP growth rate in developing countries. Journal of development economics, 32(2), 279-296. view at Google scholar / view at publisher

Bourke, P. (1989). Concentration and other determinants of bank profitability in Europe, North America and Australia. Journal of Banking \& Finance, 13(1), 65-79. view at Google scholar / view at publisher

Brewer, E., Jackson, W., \& Jagtiani, J. (2000). Impact of independent directors and the regulatory environment on bank merger prices. Evidence from takeover activity in the 1990s. view at Google scholar / view at publisher

Bris, A., Welch, I., \& Zhu, N. (2006). The costs of bankruptcy: Chapter 7 liquidation versus Chapter 11 reorganization. The Journal of Finance, 61(3), 1253-1303. view at Google scholar / view at publisher

Burger, A., \& Moormann, J. (2008). Productivity in banks: myths \& truths of the cost income ratio. Banks and Bank Systems, 3(4), 85-94. view at Google scholar

Burton, R. M., Lauridsen, J., \& Obel, B. (2002). Return on assets loss from situational and contingency misfits. Management Science, 48(11), 1461-1485. view at Google scholar / view at publisher

Central Bank of Kuwait. (2016). Banking Sector Stability Report 2016 (pp. 96). Kuwait: Central Bank of Kuwait.

Cornett, M. M., McNutt, J. J., Strahan, P. E., \& Tehranian, H. (2011). Liquidity risk management and credit supply in the financial crisis. Journal of Financial Economics, 101(2), 297-312. view at Google scholar / view at publisher

Griffith, R. (2001). Product market competition, efficiency and agency costs: an empirical analysis. IFS Working Papers, Institute for Fiscal Studies (IFS). view at Google scholar / view at publisher

Gujarati, D. N. (2009). Basic econometrics. Tata McGraw-Hill Education. view at Google scholar

Hassan Al-Tamimi, H. A., \& Mohammed Al-Mazrooei, F. (2007). Banks' risk management: a comparison study of UAE national and foreign banks. The Journal of Risk Finance, 8(4), 394409. view at Google scholar / view at publisher

Hulchanski, J. D. (1995). The concept of housing affordability: Six contemporary uses of the housing expenditure-to-income ratio. Housing studies, 10(4), 471-491. view at Google scholar I view at publisher

Jaffar, M., \& Manarvi, I. (2011). Performance comparison of Islamic and Conventional banks in Pakistan. Global Journal of Management and Business Research, 11(1), 1-7. view at Google scholar

Jiménez-Rodríguez*, R., \& Sánchez, M. (2005). Oil price shocks and real GDP growth: empirical evidence for some OECD countries. Applied Economics, 37(2), 201-228. view at Google scholar / view at publisher

Johnson, C. A., \& Rice, T. (2008). Assessing a decade of interstate bank branching. Wash. \& Lee L. Rev., 65, 73. view at Google scholar / view at publisher

Jorion, P. (2000). Value at risk (pp. 1-4). view at Google scholar

Kamran, H. W., Chaudhry, N., Murtaza, M. M., Zafar, N., Yousaf, A., \& Nazish, H. (2016). Financial market development, bank risk with key indicators and their impact on financial performance: a study from Pakistan. American Journal of Industrial and Business Management, 6(03), 373-381. view at Google scholar / view at publisher

Kamran, H. W., Khan, M. U., \& Sharif, S. (2016). Capital Structure Determinants: Evidence from Banking Sector of Pakistan. Research Journal of Finance and Accounting, 5(19), 59-66. view at Google scholar 
Karman, H. W., \& Malik, S. (2016). Risk premium and its effect on bank's non-performing loans. International Journal of Innovation and Economic Development, 1(6), 79-89. view at Google scholar / view at publisher

Katzenstein, P. J. (1985). Small states in world markets: Industrial policy in Europe. Cornell University Press. view at Google scholar

Klein, N. (2013). Non-performing loans in CESEE: Determinants and impact on macroeconomic performance. International Monetary Fund. view at Google scholar / view at publisher

Levine, R. (1999). Financial development and economic growth. views and agenda. The World Bank. view at Google scholar / view at publisher

Louzis, D. P., Vouldis, A. T., \& Metaxas, V. L. (2012). Macroeconomic and bank-specific determinants of non-performing loans in Greece: A comparative study of mortgage, business and consumer loan portfolios. Journal of Banking \& Finance, 36(4), 1012-1027. view at Google scholar / view at publisher

Modigliani, F., \& Miller, M. H. (1958). The cost of capital, corporation finance and the theory of investment. The American Economic Review, 48(3), 261-297. view at Google scholar / view at publisher

Modigliani, F., \& Miller, M. H. (1963). Corporate income taxes and the cost of capital: a correction. The American Economic Review, 53(3), 433-443. view at Google scholar

Molyneux, P., \& Thornton, J. (1992). Determinants of European bank profitability: A note. Journal of Banking \& Finance, 16(6), 1173-1178. view at Google scholar / view at publisher

Power, M. (2004). The risk management of everything. The Journal of Risk Finance, 5(3), 58-65. view at Google scholar / view at publisher

Power, M. (2005). The invention of operational risk. Review of International Political Economy, 12(4), 577-599. view at Google scholar

Raghavan, R. (2003). Risk management in banks. Chartered Accountant-New Delhi, 51(8), 841-851. view at Google scholar

Said, A. (2018). Effect of the asset quality on the bank profitability: a study of us commercial small banks. International Research Journal of Applied Finance, 9(4), 196-204. view at Google scholar

Saunders, A., \& Allen, L. (2010). Credit risk management in and out of the financial crisis. New approaches to value at risk and other paradigms (Vol. 528): John Wiley \& Sons. view at Google scholar

Stulz, R. M. (2015). Risk-taking and risk management by banks. Journal of Applied Corporate Finance, 27(1), 8-18. view at Google scholar / view at publisher

Tripe, D. (1998). Cost to income ratios in Australasian banking: Department of Finance. Banking and Property, College of Business, Massey University. view at Google scholar

Vouldis, A. T., \& Louzis, D. P. (2018). Leading indicators of non-performing loans in Greece: the information content of macro-, micro-and bank-specific variables. Empirical Economics, 54(3), 1187-1214. view at Google scholar / view at publisher

Wagner, S. M., \& Bode, C. (2008). An empirical examination of supply chain performance along several dimensions of risk. Journal of Business Logistics, 29(1), 307-325. view at Google scholar / view at publisher

Williams, C. A., \& Heins, R. M. (1985). Risk management and insurance. McGraw-Hill Companies. view at Google scholar 